\title{
Analysis of the correlation between marker compounds contents and cultivation environment of Cornus officinalis
}

\author{
Hyun Ji Eo ${ }^{1}$ (D) $\cdot$ Yeongyeong Kang $^{1}$ (D) Da Som Kim ${ }^{1}$ (D) $\cdot$ Youngki Park $^{1}$ \\ - Hyun Jun Kim ${ }^{1}$ D · Gwang Hun Park ${ }^{1}$
}

\section{산수유의 지표성분 함량과 입지환경과의 상관관계 분석}

어현지 $^{1}$ - 강연경 ${ }^{1}$. 김다솜 ${ }^{1}$ - 박영 기 ${ }^{1}$ - 김현준 ${ }^{1} \cdot$ 박광훈 $^{1}$

\begin{abstract}
The purpose of this study was to investigate the cultivation site of Cornus officinalis (C. officinalis) by analyzing the contents of loganin and morroniside according to the cultivation environment of $C$. officinalis. The loganin and morroniside contents were analyzed by ultra performance liquid chromatography. $\mathrm{Mg}$ content and $\mathrm{pH}$ in soil data were found to have the greatest effect on logainin content. In soil data, $\mathrm{Mg}, \mathrm{Na}$ content, $\mathrm{pH}$, salinity, silt ratio and clay ratio were found to have the greatest effect on morroniside content. Therefore, $\mathrm{Mg}$ content, $\mathrm{pH}$, and clay ratio were found to have a high effect on the contents of loganin and morroniside, which are indicators of $C$. officinalis. In conclusion, $\mathrm{Mg}$ content, $\mathrm{pH}$, and clay ratio in soil may have a high effect on the contents of loganin and morroniside, which are indicators of $C$. officinalis.
\end{abstract}

Keywords Cornus officinalis - Cultivation environment · Loganin · Morroniside · Ultra performance liquid chromatography

Gwang Hun Park $(\bowtie)$

E-mail: ppkh0230@korea.kr

${ }^{1}$ Forest Medicinal Resources Research Center, National Institute of Forest Science, Yeongju 36040, Republic of Korea

This is an Open Access article distributed under the terms of the Creative Commons Attribution Non-Commercial License (http://creativecommons. org/licenses/by-nc/3.0/) which permits unrestricted non-commercial use, distribution, and reproduction in any medium, provided the original work is properly cited.

\section{서 론}

산수유나무(Cornus officinalis)는 층층나무과(Cornaceae)에 속하는 낙엽수로 이른 봄에 노란색 꽃을 피우고, 가을에 붉은색의 열매 를 맺는다. 한방에서 산수유는 산수유나무 열매의 씨를 제거한 것으로 불규칙한 조각 또는 주머니 모양이고, 길이 $10-15 \mathrm{~mm}$, 너비 약 $1 \mathrm{~cm}$ 이다. 산수유의 바깥면은 어두운 적자색을 띠며 윤 이 나고 거친 주름이 있다. 산수유는 전 세계적으로 널리 사용 되는 약재 중 하나로써 의약품, 식품 및 화장품에 활용되어 인 간의 건강을 개선하고 질병을 예방한다[1-2]. 산수유 성분으로는 flovonoids 21종, triterpenes 10종, tannins 30종, saccharides 4종, monoterpenes sesquiterpenes 33종, iridoids 39종 및 essential oil이 있다고 알려져 있다. 산수유의 여러 성분 중 morroniside와 loganin은 산수유의 지표성분으로 대한약전에 명시되어 있으며[36], 항암, 항당뇨, 신경보호작용, 항염증활성, 항골다공증, 항산화 및 항노화 등 다양한 약리 활성이 있다고 밝혀져 있다[7-12]. 현 재까지 산수유나무의 개체증식, 약배양, 생장조절제, 재배지환경 조사 등 연구가 이루어져 있으나 재배환경과 지표성분과의 상관 관계 등에 대한 연구는 미비한 실정이다[13].

따라서 본 연구에서는 전국 19지역 산수유나무 재배지에서 수집한 산수유로부터 지표성분인 morroniside와 loganin의 함량 을 분석하고 토양, 해발고 등 재배환경을 조사하여 이들 상관 관계를 구명하여 산수유 최적의 재배환경요건에 대한 기초자료 를 제공하고자 하였다.

\section{재료 및 방법}

실험재료

본 실험에 사용한 산수유는 2018년 11-12월에 전국 19지역의 


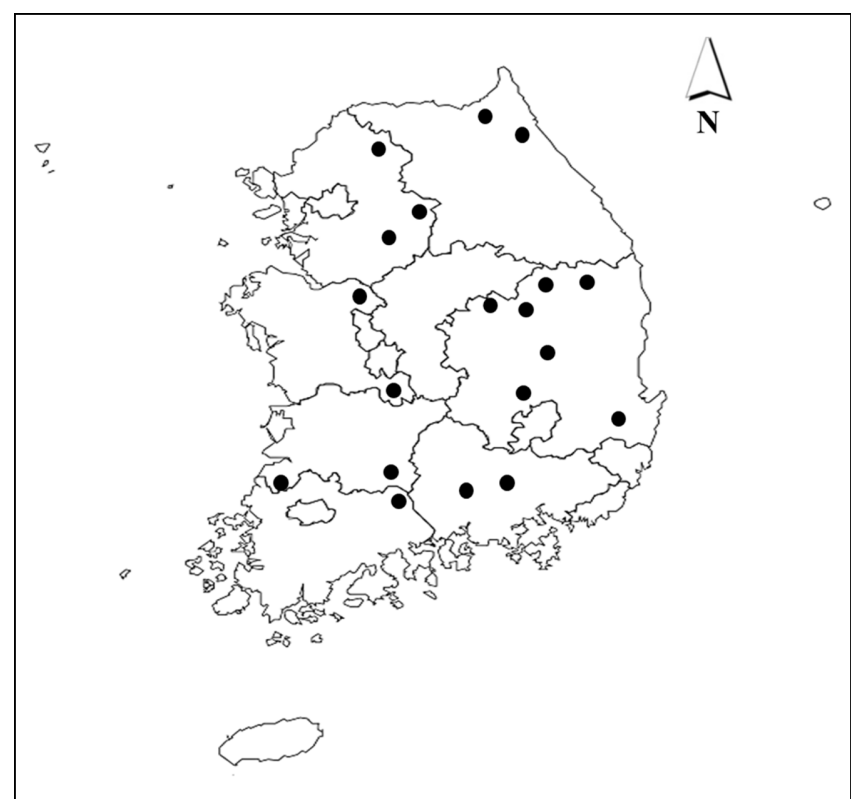

Fig. 1 Collection region of Cornus officinalis.

재배지(Fig. 1)에서 수집하였다. 관행제조 공정에 준하여 $50{ }^{\circ} \mathrm{C}$ 에서 72 시간 건조 후 $75^{\circ} \mathrm{C}$ 물에 5 분간 산수유 침지하였다. 그 후 제피기(Yousung, Korea)를 이용하여 씨를 제거한 후, $50{ }^{\circ} \mathrm{C}$ 에서 72 시간 열풍건조 후 분쇄하여 분석 시료로 사용하였다.

\section{표준품}

본 실험에서 사용된 표준용액은 morroniside (chengdu biopurify phytochemicals Ltd., chengdu, Chaina)와 loganin (chem faces, wuhan, China)을 사용하였다. Morroniside는 농도별 $(0,31.25$, $62.5,125,250,500 \mu \mathrm{g} / \mathrm{mL})$ 로 제조하였고, $\operatorname{loganin}$ 은 농도별 $(0$, $31.25,62.5,125,250,500,1,000 \mu \mathrm{g} / \mathrm{mL}$ )로 제조하였다.

\section{분석시료 추출 및 UPLC분석}

산수유 $50 \mathrm{mg}$ 에 $1 \mathrm{~mL}$ 의 $100 \%$ 메탄올을 사용하여 1 시간 초음 파 추출하였고, 추출물은 $0.2 \mu \mathrm{m}$ 멤브레인 필터(Whatman Co., Maidstone, England)로 여과하여 희석 후 분석 시료로 사용하였 다. Ultra performance liquid chromatography (UPLC, Waters, $\mathrm{MA}, \mathrm{USA})$ 분석조건은 Table 1 과 같다.

\section{재배지 토양 분석}

토양의 유기물(Organic Material, OM)은 Walkley-Black법, 질소 전량(Toatal Nitrogen, T-N)은 Kjeldhal 황산분해증류법, 유효인 산(Available- $\left.\mathrm{P}_{2} \mathrm{O}_{5}\right)$ 은 Lancaster 침출법에 의한 1-amino-2-naphtol4-sulfanic acid에 의한 몰리브덴청법, 치환성 칼륨 $(\mathrm{K}) \cdot$ 칼슘 $(\mathrm{Ca}) \cdot$ 마그네슘 $(\mathrm{Mg}) \cdot$ 나트륨 $(\mathrm{Na})$, 양이온치환용량 $($ Cation Exchange Capacity, CEC)은 $1 \mathrm{~N}-\mathrm{NH} 4 \mathrm{OAc}(\mathrm{pH} 7.0)$ 침출에 의한 분석법을 이용하였다. $\mathrm{pH}$ 와 전기전도도(Electro Conductivity, $\mathrm{EC}$ )는 풍건 세토와 증류수를 $1: 5(\mathrm{w} / \mathrm{v})$ 로 혼합하고 30 분 진탕 후 $\mathrm{pH}$ Meter와 EC Meter로 각각 측정하였다[14-15].
Table 1 UPLC operating condition for morroniside and loganin in Cornus officinals

\begin{tabular}{|c|c|c|c|}
\hline Parameter & \multicolumn{3}{|c|}{ Condition } \\
\hline$\overline{\text { Column }}$ & \multicolumn{3}{|c|}{ ACQUITY UPLC BEH C18 2.1×100 mm, $1.7 \mu \mathrm{m}$} \\
\hline Detector & \multicolumn{3}{|l|}{ UV $240 \mathrm{~nm}$} \\
\hline Mobile phase A & \multicolumn{3}{|c|}{$0.1 \%$ Formic acid in water } \\
\hline Mobile phase B & \multicolumn{3}{|c|}{$0.1 \%$ Formic acid in acetonitrile } \\
\hline Flow rate & \multicolumn{3}{|l|}{$0.17 \mathrm{~mL} / \mathrm{min}$} \\
\hline \multicolumn{4}{|c|}{ Column temperature $40{ }^{\circ} \mathrm{C}$} \\
\hline Injection volume & \multicolumn{3}{|l|}{$2 \mu \mathrm{L}$} \\
\hline \multirow{3}{*}{ Elution conditions } & Time (min) & A & $\mathrm{B}$ \\
\hline & Initial & 85 & 15 \\
\hline & 15.00 & 85 & 15 \\
\hline
\end{tabular}

\section{통계분석}

통계분석은 WEKA (Waikato Environment for Knowledge Analysis Version 3.6.4)을 이용하여 분석하였으며 각 3회 반복 실험하여 평균과 표준편차를 산출하고 $p<0.05$ 수준에서 유의성을 검정하 였다.

\section{결과 및 고찰}

\section{지표성분 함량 분석}

산수유의 품질 및 특성평가를 위한 지표성분인morroniside는 급 성심근경색, 저혈당, 신경세포 보호 효과가 있다고 알려져 있으 며[16-17], loganin은 항염증, 면역 증진, 기억력 증진 및 개선 효과 등의 효능이 있다고 보고되어 있다[18-20]. 산수유의 지표 성분인 morroniside 및 loganin 표준용액을 이용하여 검량선을 작성한 결과 morroniside 및 loganin의 상관계수 $\left(\mathrm{R}^{2}\right)$ 값은 모두 0.999 이상으로 우수한 직선성을 보였다(Fig. 2). 산수유 추출물 의 UPLC chromatogram을 비교하여 피크가 정확히 분리되는지 확인한 결과(Fig. 3), 피크 유지시간(retention time, RT)은 각각 morroniside 2.7분, loganin 4.2분으로 일치하였다. 또한, 19 지 역에서 수집된 산수유의 지표성분 함량을 분석한 결과(Table 2), 수집된 지역에 따라 morroniside와 loganin 성분 함량 차이가 났다. 재배지별로 morroniside의 함량은 적게는 $0.37 \%$, 많게는 $1.5 \%$ 로 약 4 배 이상 차이가 났고, loganin함량은 적게는 $0.27 \%$, 많게는 $1.35 \%$ 로 약 5 배 차이가 났다.

\section{재배지 토양환경 분석}

산수유나무 재배지의 토양 이화학성을 조사한 결과, Table 3과 같이 유기물함량(organic matter, $\mathrm{OM}$ )은 $0.7-11.36 \%$, 전질소 함량 (total nitrogen, $\mathrm{TN}$ )은 $0.06-0.39 \%$, 유효인산(available phosphate, Av. P)은 35.22-957.07 mg/kg, potassium $\left(\mathrm{K}^{+}\right)$는 $0.10-0.79 \mathrm{cmol}^{+} /$ $\mathrm{kg}$, calcium $\left(\mathrm{Ca}^{2+}\right)$ 는 $3.2-12.95 \mathrm{cmol}^{+} / \mathrm{kg}$, magnesium $\left(\mathrm{Mg}^{2+}\right)$ 은 $0.73-5.87 \mathrm{cmol}^{+} / \mathrm{kg}$, sodium $\left(\mathrm{Na}^{+}\right)$는 $0.02-0.20 \mathrm{cmol}^{+} / \mathrm{kg}$, 양이 온치환용량(cation exchange capacity, CEC)은 10.08-28.61 $\mathrm{cmol}^{+} / \mathrm{kg}$ 로 나타났다. Table 4와 같이 $\mathrm{pH}$ 는 4.97-6.89로 약산성, 
(A)

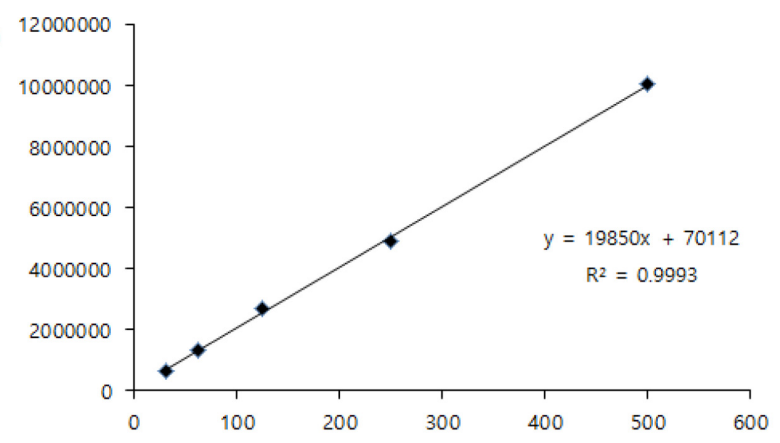

(B)

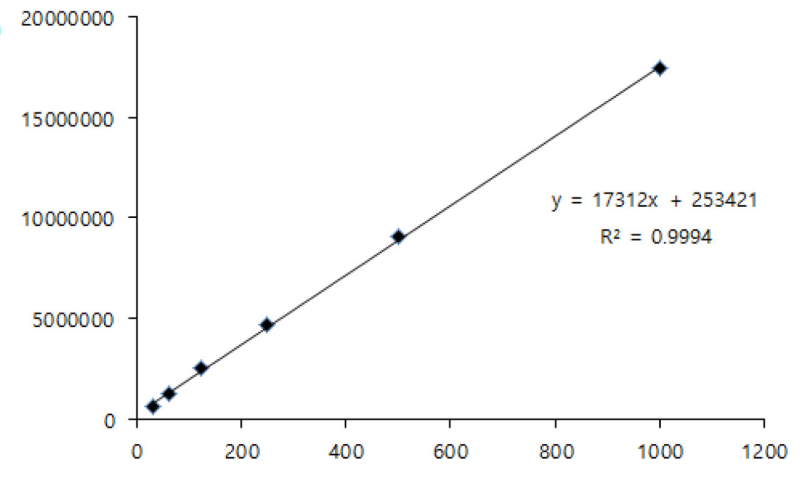

Fig. 2 Calibration curve of morroniside (A) and loganin (B)
Table 2 Contents of morroniside and loganin in Cornus officinals collected from different regions

\begin{tabular}{cccc}
\hline \hline Region & morroniside $(\%)$ & loganin $(\%)$ & Total $(\%)$ \\
\hline 1 & $0.5708 \pm 0.0045$ & $0.6542 \pm 0.0037$ & $1.2250 \pm 0.0074$ \\
2 & $0.5693 \pm 0.0029$ & $0.4226 \pm 0.0034$ & $0.9919 \pm 0.0058$ \\
3 & $0.3746 \pm 0.0025$ & $0.2706 \pm 0.0022$ & $0.6452 \pm 0.0043$ \\
4 & $0.4371 \pm 0.0033$ & $0.4243 \pm 0.0030$ & $0.8614 \pm 0.0059$ \\
5 & $1.1759 \pm 0.0032$ & $0.6051 \pm 0.0052$ & $1.7810 \pm 0.0081$ \\
6 & $0.7412 \pm 0.0024$ & $0.5689 \pm 0.0022$ & $1.3101 \pm 0.0040$ \\
7 & $0.5245 \pm 0.0066$ & $1.0973 \pm 0.0030$ & $1.6218 \pm 0.0058$ \\
8 & $0.7620 \pm 0.0020$ & $0.6490 \pm 0.0024$ & $1.4110 \pm 0.0043$ \\
9 & $1.1182 \pm 0.0014$ & $0.6392 \pm 0.0021$ & $1.7574 \pm 0.0034$ \\
10 & $0.7561 \pm 0.0029$ & $0.6681 \pm 0.0026$ & $1.4243 \pm 0.0048$ \\
11 & $0.9441 \pm 0.0022$ & $0.5667 \pm 0.0029$ & $1.5108 \pm 0.0041$ \\
12 & $0.6826 \pm 0.0018$ & $0.4557 \pm 0.0018$ & $1.1383 \pm 0.0031$ \\
13 & $0.6043 \pm 0.0012$ & $0.6072 \pm 0.0016$ & $1.2114 \pm 0.0016$ \\
14 & $0.8261 \pm 0.0026$ & $0.6056 \pm 0.0015$ & $1.4317 \pm 0.0034$ \\
15 & $1.5028 \pm 0.0009$ & $1.3509 \pm 0.0007$ & $2.8537 \pm 0.0012$ \\
16 & $0.8198 \pm 0.0026$ & $0.7992 \pm 0.0022$ & $1.6190 \pm 0.0041$ \\
17 & $0.7457 \pm 0.0024$ & $0.7005 \pm 0.0015$ & $1.4462 \pm 0.0034$ \\
18 & $1.1917 \pm 0.0037$ & $1.2136 \pm 0.0039$ & $2.4054 \pm 0.0050$ \\
19 & $0.9216 \pm 0.0024$ & $0.6462 \pm 0.0025$ & $1.5677 \pm 0.0035$ \\
\hline & & &
\end{tabular}

(A)

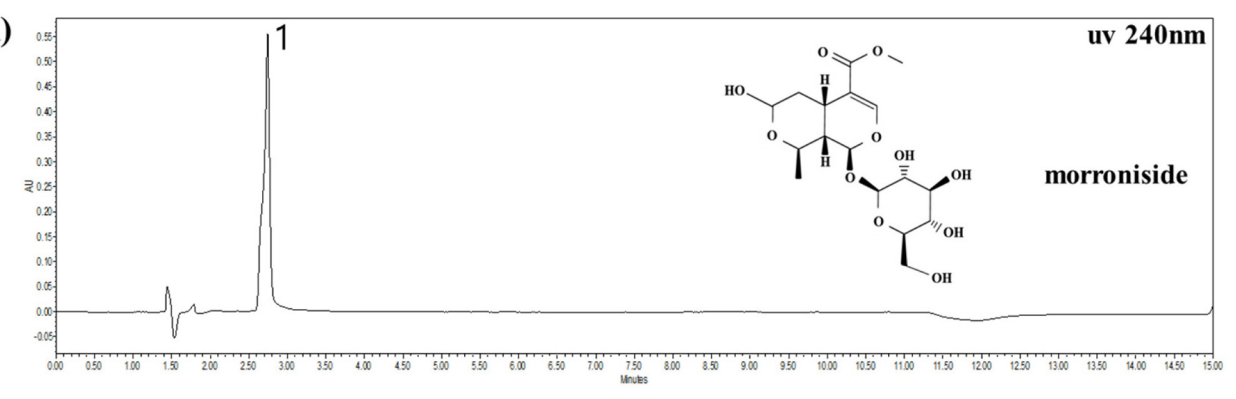

(B)

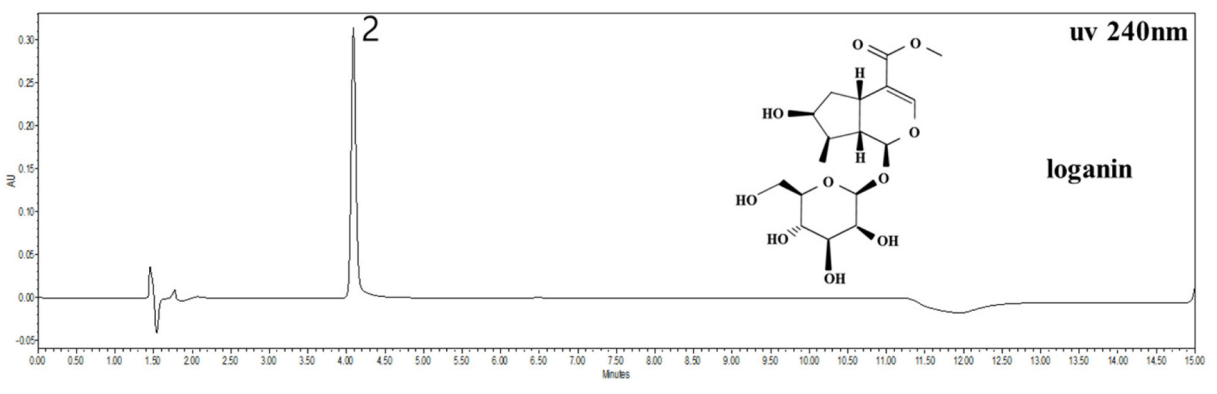

(C)

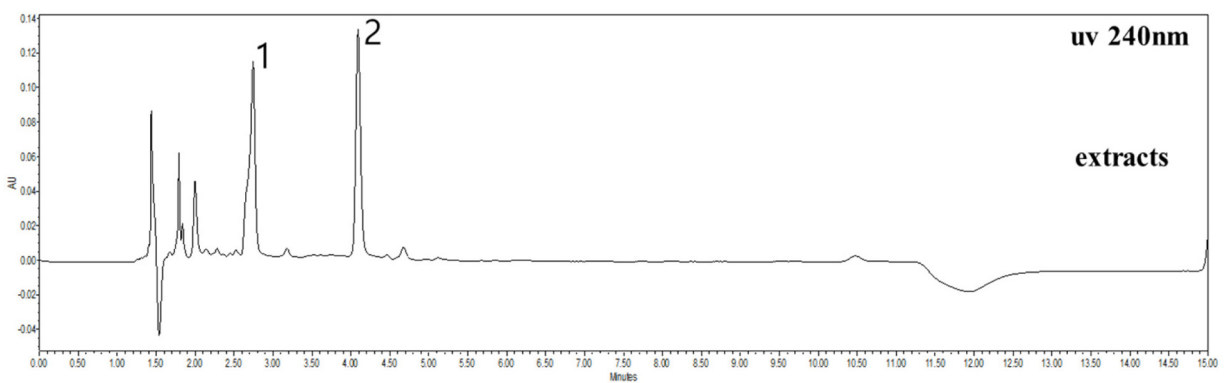

Fig. 3 UPLC chromatograms (UV $240 \mathrm{~nm}$ ) of morroniside 1000 ppm (A), loganin 1000 ppm (B), and extracts of Cornus officinalis 20000 ppm (C) 
Table 3 The content of organic matter, total nitrogen, available phosphate and exchange cation of soils collected from different regions

\begin{tabular}{|c|c|c|c|c|c|c|c|c|}
\hline \multirow[b]{2}{*}{ Region } & \multirow{2}{*}{$\begin{array}{l}\mathrm{OM} \\
(\%)\end{array}$} & \multirow{2}{*}{$\begin{array}{l}\mathrm{TN} \\
(\%)\end{array}$} & \multirow{2}{*}{$\begin{array}{c}\text { Av. P } \\
(\mathrm{mg} / \mathrm{kg})\end{array}$} & \multicolumn{4}{|c|}{ exchange cation } & \multirow{2}{*}{$\begin{array}{c}\mathrm{CEC} \\
\left(\mathrm{cmol}^{+} / \mathrm{kg}\right)\end{array}$} \\
\hline & & & & $\begin{array}{c}\mathrm{K}^{+} \\
\left(\mathrm{cmol}^{+} / \mathrm{kg}\right)\end{array}$ & $\begin{array}{c}\mathrm{Ca}^{2+} \\
\left(\mathrm{cmol}^{+} / \mathrm{kg}\right)\end{array}$ & $\begin{array}{c}\mathrm{Mg}^{2+} \\
\left(\mathrm{cmol}^{+} / \mathrm{kg}\right)\end{array}$ & $\begin{array}{c}\mathrm{Na}^{+} \\
\left(\mathrm{cmol}^{+} / \mathrm{kg}\right)\end{array}$ & \\
\hline 1 & 2.03 & 0.13 & 178.62 & 0.31 & 6.14 & 0.73 & 0.15 & 11.30 \\
\hline 2 & 0.95 & 0.06 & 281.10 & 0.10 & 4.78 & 0.76 & 0.15 & 11.39 \\
\hline 3 & 2.82 & 0.17 & 241.07 & 0.43 & 7.10 & 1.46 & 0.20 & 11.92 \\
\hline 4 & 5.43 & 0.28 & 957.07 & 0.76 & 7.26 & 2.14 & 0.15 & 15.78 \\
\hline 5 & 1.40 & 0.08 & 485.14 & 0.39 & 3.63 & 0.74 & 0.18 & 10.41 \\
\hline 6 & 2.49 & 0.17 & 315.14 & 0.33 & 5.77 & 1.40 & 0.20 & 11.57 \\
\hline 7 & 1.84 & 0.12 & 45.10 & 0.29 & 12.03 & 3.49 & 0.14 & 11.58 \\
\hline 8 & 11.36 & 0.39 & 178.16 & 0.79 & 12.61 & 2.65 & 0.11 & 28.61 \\
\hline 9 & 0.70 & 0.05 & 35.22 & 0.10 & 9.00 & 0.98 & 0.08 & 11.64 \\
\hline 10 & 3.58 & 0.19 & 485.84 & 0.68 & 6.11 & 1.15 & 0.06 & 13.17 \\
\hline 11 & 3.91 & 0.21 & 304.02 & 0.40 & 7.67 & 0.83 & 0.02 & 11.99 \\
\hline 12 & 4.58 & 0.19 & 469.08 & 0.56 & 10.79 & 1.72 & 0.07 & 12.87 \\
\hline 13 & 1.98 & 0.11 & 549.06 & 0.45 & 3.20 & 0.69 & 0.11 & 10.08 \\
\hline 14 & 1.65 & 0.09 & 212.84 & 0.19 & 4.93 & 0.70 & 0.03 & 10.87 \\
\hline 15 & 3.29 & 0.19 & 164.89 & 0.33 & 12.95 & 5.20 & 0.06 & 12.87 \\
\hline 16 & 2.31 & 0.16 & 153.57 & 0.26 & 6.63 & 0.83 & 0.03 & 11.77 \\
\hline 17 & 1.29 & 0.15 & 300.75 & 0.57 & 5.79 & 0.83 & 0.05 & 12.17 \\
\hline 18 & 2.91 & 0.14 & 115.76 & 0.14 & 7.97 & 5.87 & 0.04 & 13.13 \\
\hline 19 & 2.74 & 0.13 & 74.07 & 0.21 & 7.28 & 2.31 & 0.04 & 12.78 \\
\hline
\end{tabular}

Table 4 The content of $\mathrm{pH}$, electrical conductivity, salinity and earthiness of soils collected from different regions

\begin{tabular}{|c|c|c|c|c|c|c|}
\hline \multirow{2}{*}{ Region } & \multirow{2}{*}{$\mathrm{pH}[1: 5]$} & \multirow{2}{*}{$\mathrm{EC}[1: 5](\mathrm{dS} / \mathrm{m})$} & \multirow{2}{*}{ salinity (\%) } & \multicolumn{3}{|c|}{ earthiness } \\
\hline & & & & sand $(\%)$ & silt (\%) & clay $(\%)$ \\
\hline 1 & 6.58 & 0.07 & 0.006 & 72.78 & 20.99 & 6.23 \\
\hline 2 & 5.56 & 0.04 & 0.006 & 72.85 & 17.96 & 9.19 \\
\hline 3 & 6.20 & 0.12 & 0.005 & 75.87 & 19.98 & 4.15 \\
\hline 4 & 6.27 & 0.18 & 0.006 & 75.44 & 18.20 & 6.36 \\
\hline 5 & 5.66 & 0.07 & 0.004 & 74.74 & 17.88 & 7.38 \\
\hline 6 & 5.55 & 0.09 & 0.006 & 73.98 & 18.92 & 7.11 \\
\hline 7 & 6.36 & 0.10 & 0.004 & 74.23 & 21.15 & 4.62 \\
\hline 8 & 5.97 & 0.21 & 0.006 & 75.59 & 17.96 & 6.45 \\
\hline 9 & 6.16 & 0.05 & 0.004 & 78.04 & 17.35 & 4.60 \\
\hline 10 & 6.01 & 0.12 & 0.004 & 72.78 & 20.02 & 7.28 \\
\hline 11 & 6.14 & 0.12 & 0.003 & 71.09 & 17.42 & 11.48 \\
\hline 12 & 6.89 & 0.16 & 0.004 & 70.21 & 7.82 & 21.97 \\
\hline 13 & 4.94 & 0.10 & 0.005 & 76.04 & 19.29 & 4.67 \\
\hline 14 & 5.72 & 0.07 & 0.002 & 74.64 & 18.16 & 7.21 \\
\hline 15 & 4.97 & 0.10 & 0.003 & 73.30 & 7.18 & 19.52 \\
\hline 16 & 5.80 & 0.11 & 0.002 & 74.68 & 20.23 & 5.09 \\
\hline 17 & 5.76 & 0.14 & 0.003 & 73.56 & 19.27 & 7.17 \\
\hline 18 & 5.10 & 0.05 & 0.002 & 74.30 & 4.58 & 21.12 \\
\hline 19 & 6.52 & 0.05 & 0.003 & 72.75 & 15.55 & 11.70 \\
\hline
\end{tabular}


Table 5 Correlation between the soil chemical properties and index compounds (loganin and morroniside) in Cornus officinalis using WEKA

\begin{tabular}{lcc}
\hline \hline soil chemical properties & loganin & morroniside \\
\hline $\mathrm{OM}(\%)$ & -0.13 & -0.11 \\
Total $\mathrm{N}(\%)$ & -0.12 & -0.13 \\
$\mathrm{Av} . \mathrm{P}(\mathrm{mg} / \mathrm{kg})$ & $-0.38^{*}$ & -0.21 \\
$\mathrm{~K}^{+}\left(\mathrm{cmol}^{+} / \mathrm{kg}\right)$ & -0.22 & -0.23 \\
$\mathrm{Ca}^{2+}\left(\mathrm{cmol}^{+} / \mathrm{kg}\right)$ & 0.22 & 0.20 \\
$\mathrm{Mg}^{2+}\left(\mathrm{cmol}^{+} / \mathrm{kg}\right)$ & $0.66^{* * *}$ & $0.41^{*}$ \\
$\mathrm{Na}^{+}\left(\mathrm{cmol}^{+} / \mathrm{kg}\right)$ & -0.38 & $-0.48^{*}$ \\
$\mathrm{CEC}\left(\mathrm{cmol}^{+} / \mathrm{kg}\right)$ & -0.008 & -0.001 \\
$\mathrm{pH}[1: 5]$ & $-0.44^{*}$ & $-0.41^{*}$ \\
$\mathrm{EC}[1: 5](\mathrm{dS} / \mathrm{m})$ & -0.21 & -0.21 \\
salinity $(\%)$ & -0.24 & -0.38 \\
sand $(\%)$ & -0.13 & -0.011 \\
silt $(\%)$ & -0.21 & $-0.49^{*}$ \\
clay $(\%)$ & $037^{*}$ & $0.47^{*}$ \\
\hline
\end{tabular}

*Significant at $p<0.05, * *$ Significant at $p<0.01, * * *$ Significant at $p<0.001$

전기전도도(electrical conductivity)는 $0.04-0.21 \mathrm{dS} / \mathrm{m}$, 염도(salinity) 는 $0.002-0.006 \%$, 토성은 양질사토-사양토로 나타났다.

\section{지표성분과 입지환경과의 상관관계 분석}

Park 등[21]이 보고한 산수유 주산지 환경조사 결과에 따르면 산 수유는 일교차가 크고, 해발고도 $100-400 \mathrm{~m}$ 내의 남동향 지대에 서 결실율이 좋으며 토양조건은 배수가 잘된 사질토로서 약산성 $\left(\mathrm{pH}\right.$ 6.2-6.6)이며 경사 $15^{\circ}$ 이내로서 한파의 영향이 크지 않은 지 대에 적응하고 있다고 하였다. Morroniside와 loganin의 재배환경 간 상관관계 분석한 결과(Table 5), loganin과 토양 데이터 중 $\mathrm{Mg}^{2+}$ 함량과 $\mathrm{pH}$ 가 가장 큰 영향을 미치는 것으로 확인되었다. 토양의 $\mathrm{Mg}^{2+}$ 함량은 loganin과 양의 상관관계, $\mathrm{pH}$ 는 loganin과 음의 상관관계인 것으로 확인되었다. 산수유 지표성분인 Morroniside와 토양 데이터 중 $\mathrm{Mg}^{2+}$ 함량, $\mathrm{Na}^{+}$함량, $\mathrm{pH}$, 염도, silt 비율, clay 비율이 가장 큰 영향을 미치는 것으로 확인되었 다. 이러한 인자들은 일반적으로 작물의 양분 흡수와 관련이 있 고, 식물의 생육에 영향을 미치므로[22] 지표성분과도 높은 상관 관계가 있는 것으로 보인다. 따라서 토양 데이터 중 $\mathrm{Mg}^{2+}$ 함량, $\mathrm{pH}$, clay 비율이 산수유의 지표물질인 morroniside와 loganin의 함량에 높은 영향을 미치는 것으로 확인되었다. 토양의 $\mathrm{Mg}^{2+}$ 함 량이 $2.93 \mathrm{cmol}^{+} / \mathrm{kg}$ 이상일 때, $0.9 \%$ 이상의 loganin 함량을 나타내 고, 토양의 silt 비율이 $17.88 \%$ 이하이고, $\mathrm{K}$ 함량이 $0.45 \mathrm{cmol}^{+} /$ $\mathrm{kg}$ 이하일 때, morroniside 함량이 $0.9 \%$ 이상인 것으로 예측된다. 결론적으로 본 연구에서는 산수유의 지역별 지표성분 함량을 분석하였고, 재배 토양환경에 따른 loganin, morroniside 함량의 상관관계를 분석하였다. 이를 통해 산수유나무의 최적의 재배환 경요건에 대한 기초자료를 제공할 수 있을 것이다.

\section{초 록}

본 연구에서는 재배 환경에 따른 산수유나무의 지표성분인 loganin 및 morroniside을 함량 분석을 통한 상관관계 구명하고 자 하였다. Loganin 및 morroniside 함량은 UPLC에 의해 동시 분석되었다. 토양 데이터의 $\mathrm{Mg}^{2+}$ 함량과 $\mathrm{pH}$ 가 loganin 함량에 가장 큰 영향을 미치는 것으로 나타났으며 $\mathrm{Mg}^{2+}, \mathrm{Na}^{+}$함량, $\mathrm{pH}$, 염도, silt 비율, 점토 비율이 morroniside 함량에 가장 큰 영향을 미치는 것으로 나타났다. 결론적으로 $\mathrm{Mg}^{2+}$ 함량, $\mathrm{pH}$, 점 토비율은 산수유 지표성분인 morroniside 및 loganin 함량에 높 은 영향을 미치는 것으로 나타났다. 이러한 결과들은 산수유나 무의 최적의 재배환경요건에 대한 기초자료로 이용될 수 있을 것으로 기대된다.

Keywords Cornus officinalis - Cultivation environment ·

Loganin · Morroniside · Ultra performance liquid chromatography

감사의 글 본 연구는 국립산림과학원 일반연구사업(과제번호: FP0400-201701)지원에 의해 이루어진 결과로 이에 감사드립니다.

\section{References}

1. Kwon BS, Kim HJ (1999) Current cultivation status fo Corunn officinalis S. et Z. in Sangdong-myun, Gurye-gu, Korea. Journal of national sciences soonchunhyang university 18: 67-73

2. Lee HJ, Do JR, Kwon JH, Kim HK (2012) Physiological properties of Corni fructus extracts based on their extraction condition. The Korean Society of Food Preservation 19: 271-277

3. Lee YC, Kim YE, Lee BY, Kim CJ (1992) Chemical compositions of Corni Fructus and separating properties of its flesh by drying. Korean Journal of Food Science Technology 24: 447-450

4. Cao G, Cai H, Cai B, Tu S (2013) Effect of 5-hydroxymethylfurfural derived from processed Cornus officinalis on the prevention of high glucose-induced oxidative stress in human umbilical vein endothelial cells and its mechanism. Food Chemistry 140: 273-279

5. Jang DE, Lee SH, Hwang IG, Song J, Hwang KA (2016) Method validation for the analysis of loganin content in Cornus Officinals depends on cultivation regions. Food Engineering Progress 20: 152-157

6. Dong Y, Feng ZL, Chen HB, Wang FS, Lu JH (2018) Corni Fructus: a review of chemical constituents and pharmacological activities. Chinese Medicine 13: 1-20

7. Seo KI, Lee SW, Yang KH (1999) Antimicrobial and antioxidative activiteis of Corni Fructus extracts. Korean Journal of Postharvest Science Technology 6: 99-103

8. Lee WB, Jung HS, Kwon J, Oh CH, Lee KG (2002) Immunoregulatory action of Cornus officinalis Sieb. et Zucc. Korean Journal of Physiology \& Pathology 16: 267-271

9. Lee SO (2003) Composition and functional properties of Cornus officinalis and its application to food. Dissertation, Sejong University

10. Jeon YH, Kim MH, Kim MR (2008) Antioxidative, Antimutagenic, and Cytotoxic Activities of Ethanol Extracts from Cornus officianalis. The Korean Society of Food Science and Nutrition 37: 1-7

11. Park SJ, Jeong JS, Jeong JH, Park NJ, Son BG (2017) Morroniside, loganin, and cornin contents and physicochemical properties of commercial sansuyu (Corni fructus) retort drink. The Korean Society of Food Science and Nutrition 46: 1018-1025

12. Huang J, Zhang Y, Dong L, Gao Q, Yin L, Quan H,Chen R, Fu X, Lin D (2018) Ethnopharmacology, phytochemistry, and pharmacology of Cornus officinalis Sieb. et Zucc. Journal of Ethnopharmacology 213: 280-301

13. Lee YH (1975) Fruit tree cultivation-Cornus officinalis. Korean poultry journal 8: 98-114

14. De Vos B, Lettens S, Muys B, Deckers JA (2007) Walkley-Black 
analysis of forest soil organic carbon: recovery, limitations and uncertainty. Soil Use and Management 23: 221-229

15. Lee HJ, Lee CH, Kang BS, Ahn BK (2010) Investigations of soil chemical properties in the cultivation fields of Rubus coreanus with different growth ages. Korean Society of Soil Science and Fertilizer 43: 923-929

16. Wang W, Sun F, An Y, Ai H, Zhang L, Huang W, Li L (2009) Morroniside protects human neuroblastoma SH-SY5Y cells against hydrogen peroxide-induced cytotoxicity. European Journal of Pharmacology 613: 19-23

17. He K, Song S, Zou Z, Feng M, Wang D, Wang Y, Li X, Ye X (2016) The hypoglycemic and synergistic effect of loganin, morroniside, and ursolic acid isolated from the fruits of Cornus officinalis. Phytotherapy Research 30: 283-291
18. Li X, Wang Q, Zhang L, Xu L, Yin W (2006) HPLC study of tissue distribution of loganin in rats. Biomedical Chromatography 20: 1087 1092

19. Kwon SH (2008) Effect of loganin on learning and memory in mice. Dissertation, Sungkyunkwan University

20. Kim H (2013) Loganin attenuated Aâ(25-35)-Induced cell injuryand NF$\kappa \mathrm{B}$ signaling pathway in PC12 cells. Dissertation, Dong-A University

21. Park GC, Park IJ, Lee WJ, Park TD (1994) Investigation of cultural environment and effect of plant growth regulator on japanese cornel dogwood (Macrocarpium officinale NAKAI). Korean Journal of Medicinal Crop Science 2: 1-6

22. Havlin JL, Tisdale SL, Nelson WL, Beaton JD (2013) Soil Fertility and Fertilizers, 8th edition. Published by Pearson 